SCIDic

\section{Submucosal Dexamethasone Vs Intramuscular Dexamethasone in Surgical Extraction of Third Molars- A Retrospective Study}

ISSN: $2377-8075$

Research Article

Harini $\mathrm{G}^{1}$, Dinesh Prabu ${ }^{2 *}$, Balakrishnan $\mathrm{RN}^{3}$

${ }^{1}$ Saveetha Dental College and Hospitals, Saveetha Institute of Medical and Technical Sciences, Saveetha University, Chennai, India.

${ }^{2}$ Senior Lecturer, Department of Oral and Maxillofacial Surgery, Saveetha Dental College and Hospitals, Saveetha Institute of Medical and Technical Sciences, Saveetha University, Chennai, 600077, India.

${ }^{3}$ Senior Lecturer, Department of Oral and Maxillofacial Surgery, Saveetha Dental College and Hospitals, Saveetha Institute of Medical and Technical Sciences, Saveetha University, Chennai, 600077, India.

\title{
Abstract
}

Transalveolar extraction of mandibular third molar is a cumbersome and dreaded procedure. For most of the patient it brings discomfort to interfere the daily chores because of post pain, swelling and trismus. In this prospective randomised study, we evaluate the effect of dexamethasone of pain,swelling and trismus. A total of 44 patients were enrolled in this prospective study that are divided into two groups. Group A (22 patients) to receive submucosal dexamethasone and Group B (22 patients) to receive intramuscular dexamethasone postoperative to the mandibular third molar extraction. Equal number of males and females in both groups are taken in this study. SPSS software was used for analysis. There was no significant difference in the demographic data and duration of surgery between the groups.pain and trismus was more marked on the 3rd day and slowly reduced but no significant difference between the groups. They give comparable result when used intraoperatively during third molar surgery.

Keywords: Dexamethasone; Intramuscular; Prospective; Submucosal; Transalveolar Surgery.

\section{Introduction}

Sometimes a tooth may fail to emerge into proper alignment and remains "entrapped" in the gum tissue and jaw bone. Such a tooth is referred to as an impact. Impactions may occur due to various reasons. For example, the jaw may be too small and there may be insufficient space for the teeth to erupt. Teeth may also become twisted, tilted, or displaced as they try to emerge, resulting in impacted teeth. The most common impacted teeth are wisdom teeth or third molars.

Impacted teeth may result in swelling, pain and infection of surrounding gum tissue. Also, impacted teeth may cause permanent damage to nearby teeth or lead to the formation of cysts or tumors that can destroy sections of the jaw. Therefore, it is often recommended that impacted teeth be promptly removed. Transalveolar extraction of impacted third molars is the most commonly found procedure by oral and maxillofacial surgeons
[1]. It involves intentional and minor trauma to the hard and soft tissue surrounding the teeth that generally leads to pain ,swelling and trismus that brings the patient discomfort for social well being [2]. The prime concern of each and every dentist is to reduce the postoperative sequelae.

This extraction can involve injury which further cause trauma leading to inflammation due to action of phospholipase.These are preferred to act as mediators of inflammation. This peaks during the 2 nd day after extraction [3]. The first step is to reduce inflammation caused due to injury this leads to reduction in fluid translation and a decrease in edema [4]. These corticosteroid drugs can be administered orally, submucosally or intravenously. Even though there are many routes there is no clear evidence that provide quick relief [5]. In this prospective randomisedstudy,we evaluate the effect of dexamethasone by either giving submucosal or by intramuscular route to reduce on pain, swelling and trismus.

*Corresponding Author:

Dr. Dinesh Prabu,

Senior Lecturer, Department of Oral and Maxillofacial Surgery, Saveetha Dental College and Hospitals, Saveetha Institute of Medical and Technical Sciences, Saveetha University, Chennai, 600077, India.

E-mail: dineshprabum.sdc@saveetha.com

Received: November 10, 2020

Accepted: December 15, 2020

Published: December 18, 2020

Citation: Harini G, Dinesh Prabu, Balakrishnan RN. Submucosal Dexamethasone Vs Intramuscular Dexamethasone in Surgical Extraction of Third Molars- A Retrospective Study. Int J Dentistry Oral Sci. 2020;7(12):1222-1225. doi: http://dx.doi.org/10.19070/2377-8075-20000241

Copyright: Dinesh Prabu ${ }^{\circ} 2020$. This is an open-access article distributed under the terms of the Creative Commons Attribution License, which permits unrestricted use, distribution and reproduction in any medium, provided the original author and source are credited. 


\section{Materials And Methods}

- This Study was conducted in the oral and maxillofacial surgery department .Datas were collected by reviewing the patient records and analysed the data of 86,000 patients. Group-A-Sub-mucosal dexamethasone and Group-B-Intramuscular dexamethasone. Total of which 44 patients were involved who undergone mandibular third molar extraction.

- Both male and female were taken equally in both the groups for this study.

\section{Inclusion Criteria}

18-48 years with no active infection at time of extraction .

\section{Exclusion Criteria}

- Immunocompromised patients

- Patient with allergic reaction to lignocaine,dexamethasone.

- Patient with steroid use.

- Lactation and pregnant women.

- Using antibiotics are excluded in the study.

\section{Statistical Analysis}

The data was analysed using SPSS software by means of the value to be recorded and the test of significance was applied in chisquare test. The probability value of less than 0.05 considered as significant.

\section{Results And Discussion}

A total of 44 patients were enrolled in the prospective study. This study was conducted from 1st april 2019-1 ${ }^{\text {st }}$ april 2020

Table-1 illustrates the demographic data related to the patience and mean duration of surgery among the groups. The mean age in group A was 30.6 yrs+/- 4.6 years and group B was 29.6 yrs+/5.2 years. Equal gender with 22 patients was taken for both group$A$ and Group-B. The mean time duration of surgery was less than 30 minutes.

The other table-2 illustrates the comparison of pain score among both the groups. On 7 th postoperative day Group A and Group B, no patient had severe pain. Group A - 4 patients had moderate pain, 9 patients had mild pain and 9 patients had no pain. In group B only 2 patients had moderate pain 10 patients had mild pain and 10 patients had no pain, there was no statistical significant difference between the groups on $3 \mathrm{rd}$ and 7 th postoperative day. Pearson chi-square value-1.034 and p-value was found to be 0.73 for 3rd post-operative day and Pearson chi-square value-2.062 and $\mathrm{p}$ value was found to be 0.35 for 5 th postoperative day this implies that there are no statistical significance between two groups.

Removal of the mandibular wisdom tooth is one of the most painful,frightful and dreadful amongst patients [6]. Its associated consequences like pain,swelling and trismus can interfere with patient social well being, Operators are trying their best to reduce this discomfort.Various techniques and medications are put into to reduce sequelae [7]. Corticosteroids like dexamethasone and methylprednisolone because of their pure glucocorticoids and

Figure 1. Bar graph shows Third postoperative day association between pain scores and groups. X-axis denotes severity of pain and Y-axis denotes no.of.patients. In both Group-A and Group-B Moderate and severe pain was experienced during the 3rd post operative day. $27 \%$ of the patient in Group-A (Blue) experienced moderate pain. However the test was found to be statistically non-significant using Chi-square test (Pearson chi-square value-0.94 and p-value-0.763).

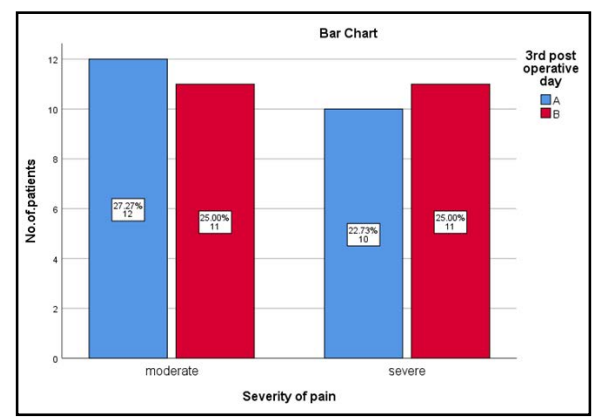

Figure 2. Bar graph shows seventh postoperative day association between pain and groups. $\mathrm{X}$-axis denotes severity of pain and $\mathrm{Y}$-axis denotes the number of patients. In both Group-A and Group-B patients experienced no pain,moderate and mild pain. Majority of patients in both Group-A (Blue) and Group-B (pink) experienced a range of mild to no pain.Therefore, the difference was found to be statistically not significant (Pearson chi-square-1.983 and p-value-0.98).

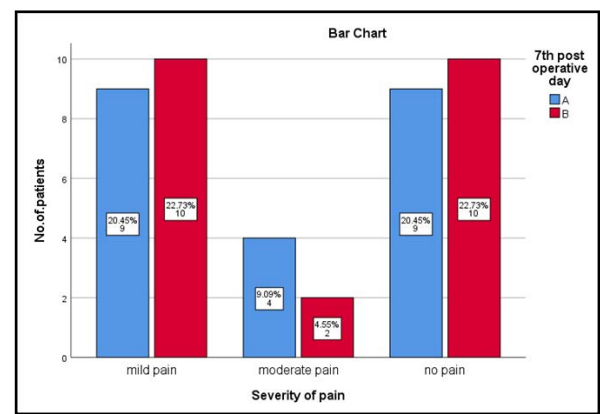


Table 1. Shows the variables of age,gender and duration of surgery. The mean age of the patient participated in the study in Group-A is $30.6 \pm 4.6$ years and Group-B is $29.6 \pm 5.2$ years. Equal distribution of gender was taken in both the groups. The duration of surgery done in both groups are less than 30 minutes.

\begin{tabular}{|c|c|c|c|}
\hline \multicolumn{2}{|c|}{ Variables } & $\begin{array}{c}\text { GROUP } \\
\text { A(Submucosal) }\end{array}$ & $\begin{array}{c}\text { GROUP } \\
\text { B(Intramuscular) }\end{array}$ \\
\hline \multicolumn{2}{|c|}{ Age (Mean) } & $30.6 \pm 4.6 y e a r s$ & $29.6 \pm 5.2$ years \\
\hline \multirow{2}{*}{ Gender n $(\%)$ Female } & $11(25 \%)$ & $11(25 \%)$ \\
\cline { 2 - 4 } & Male & $11(25 \%)$ & $11(25 \%)$ \\
\hline \multicolumn{2}{|c|}{ Duration of surgery } & $>30$ minutes & $>30$ minutes \\
\hline
\end{tabular}

Table 2. Comparison of pain scores(VAS) between group A and group B. Chi-square test was used to find difference between the groups at 3 rd postoperative day(Pearson chi-square value-1.034; $\mathrm{p}>0.05$ ) and 7 th postoperative day (Pearson chi-square value-2.062; $\mathrm{p}>\mathbf{0 . 0 5}$ ). Even Though the test was found to be statistically not significant, severe pain score was observed at 3rd postoperative day among $11(50 \%)$ study subjects in Group B and during 7th postoperative day, moderate pain was experienced by $4(20 \%)$ in Group $A$.

\begin{tabular}{|c|c|c|c|c|c|}
\hline $\begin{array}{l}\text { TIME OF } \\
\text { SURGERY }\end{array}$ & VAS & $\begin{array}{c}\text { GROUP-A } \\
n(\%)\end{array}$ & $\begin{array}{c}\text { GROUP-B } \\
n(\%)\end{array}$ & $\begin{array}{l}\text { Pearson chi- } \\
\text { square value }\end{array}$ & P-value \\
\hline \multirow{4}{*}{$\begin{array}{l}\text { 3rd postop- } \\
\text { erative day }\end{array}$} & No pain(score $0-1$ ) & $0(0 \%)$ & $0(0 \%)$ & \multirow{4}{*}{1.034} & \multirow{4}{*}{0.73} \\
\hline & Mild pain(score 1-3) & $0(0 \%)$ & $0(0 \%)$ & & \\
\hline & Moderate pain(score 4-6) & $12(54 \%)$ & $11(50 \%)$ & & \\
\hline & Severe pain(score 7-9) & $10(46 \%)$ & $11(50 \%)$ & & \\
\hline \multirow{4}{*}{$\begin{array}{l}\text { 7th postop- } \\
\text { erative day }\end{array}$} & No pain(score $0-1$ ) & $9(40 \%)$ & $10(45 \%)$ & \multirow{4}{*}{2.062} & \multirow{4}{*}{0.35} \\
\hline & Mild pain(score (1-3) & $9(40 \%)$ & $10(45 \%)$ & & \\
\hline & Moderate pain (4-6) & $4(20 \%)$ & $2(10 \%)$ & & \\
\hline & Severe pain(7-9) & $0(0 \%)$ & $0(0 \%)$ & & \\
\hline
\end{tabular}

no mineral solid effort can been used in dentoalveolar surgery and least adverse effect on leukocyte chemotaxis [8, 9]. Hence they have gained widespread importance in this arene [10]. In metaanalysis by [11], he interfered that giving corticosteroids like dexamethasone has mild to moderate value in reduction of postoperative inflammatory signs and symptoms.

El hag et al [11] in their study compared $1 \mathrm{mg}$ dexamethasone injection he included the significant reduction Dexamethasone has half life of 36-72 hours. He concluded that there is significant reduction in swelling and trismus following third molar surgery. According to a study [12], marked reduction in pain, swelling and trismus were seen after administration of intravenous $125 \mathrm{mg}$ of methylprednisolone preoperatively following mandibular third surgery. According to a similar study conducted by [13], a marked reduction in oedema was seen on the first postoperative day but there was a rebound increase in oedema on the 2 nd and 3 rd post operative day. Dexamethasone has a half life of 36-72 hours. Corticosteroids stabilize the lysosomal membrane and therefore prevent the release of proteolytic enzymes. They also decrease the capillary permeability and therefore lead to reduction in oedema [14].

According to our study there was no significant difference in trismus in both the groups which correlated with the study done by [15] where intramuscular application of dexamethasone produced marked reduction in trismus but its submucosal administration did not produce notable results Various factors such as age ,gender and operating time have also been seen to influence healing and swelling after surgery. But in our study these variables were insignificant and the same surgeon performed all the surgery therefore no impact. Considerable research has been conducted in the field of oral and maxillofacial surgery with relevance to the current population under study [16-30]. This study attempts to identify the effectiveness among the population. Further studies with a larger population is advised.

\section{Conclusion}

From the results of present study we can conclude that submucosal or intramuscular dexamethasone has no significant difference in postoperative sequela and therefore any route can be used after surgery without many variations. Dexamethasone given submucosally or intramuscularly is an effective way of minimising swelling, trismus, and pain after removal of impacted lower third molars, and is comparable with the intramuscular route. It offers a simple, safe, painless, non-invasive, and cost-effective treatment in moderate and severe cases.

\section{Authors Contribution}

First author (Harini $G$ ) performed analysis,and interpretation and wrote the manuscript. Second author (Dr Dinesh Prabu) contributed to conception, datadesigns, analysis, interpretation and critically revised the manuscript. Third author (Dr.Bala Krishnan R $\mathrm{N})$ participated in the study and revised the manuscript. All the three authors have discussed the results and contributed to the final manuscript. 


\section{Acknowledgement}

This study was supported by Saveetha institute of technical and medical sciences, Chennai.

\section{References}

[1]. Shepherd JP, Brickley M. Surgical removal of third molars [Internet]. BMJ. 1994; 309: 620-1.

[2]. Grossi GB, Maiorana C, Garramone RA, Borgonovo A, Beretta M, Farronato $D$, Santoro $F$. Effect of submucosal injection of dexamethasone on postoperative discomfort after third molar surgery: a prospective study. Journal of oral and maxillofacial surgery. 2007 Nov 1;65(11):2218-26.

[3]. Savin J, Ogden GR. Third molar surgery-a preliminary report on aspects affecting quality of life in the early postoperative period. British journal of oral and maxillofacial surgery. 1997 Aug 1;35(4):246-53.

[4]. Troullos ES, Hargreaves KM, Butler DP, Dionne RA. Comparison of nonsteroidal anti-inflammatory drugs, ibuprofen and flurbiprofen, with methylprednisolone and placebo for acute pain, swelling, and trismus. J Oral Maxillofac Surg. 1990 Sep;48(9):945-52.Pubmed PMID: 2395047.

[5]. Messer EJ, Keller JJ. The use of intraoral dexamethasone after extraction of mandibular third molars. Oral Surg Oral Med Oral Pathol. 1975 Nov;40(5):594-8. PubmedPMID: 1059060.

[6]. Milles M, Desjardins PJ. Reduction of postoperative facial swelling by lowdose methylprednisolone: an experimental study. J Oral Maxillofac Surg. 1993 Sep;51(9):987-91. PubmedPMID: 8355105.

[7]. Alexander RE, Throndson RR. A review of perioperative corticosteroid use in dentoalveolar surgery. Oral Surg Oral Med Oral Pathol Oral RadiolEndod. 2000 Oct;90(4):406-15. PubmedPMID: 11027375

[8]. Hupp JR. Principles of Management of Impacted Teeth [Internet]. Contemporary Oral and Maxillofacial Surgery. 2014. p. 143-67.

[9]. Montgomery MT, Hogg JP, Roberts DL, Redding SW. The use of glucocorticosteroids to lessen the inflammatory sequelae following third molar surgery. J Oral Maxillofac Surg [Internet]. 1990 Feb;48(2):179-87. PubmedPMID: 2405122.

[10]. Francis FH, Bosshardt LL. Ankylosis of multiple impacted premolars. Oral Surg Oral Med Oral Pathol. 1969 Dec;28(6):855. PubmedPMID: 5260655.

[11]. Gersema L, Baker K. Use of corticosteroids in oral surgery [Internet]. Vol. 50, Journal of Oral and Maxillofacial Surgery. 1992. p. 270-7.

[12]. Markiewicz MR, Brady MF, Ding EL, Dodson TB. Corticosteroids reduce postoperative morbidity after third molar surgery: a systematic review and meta-analysis. J Oral Maxillofac Surg. 2008 Sep;66(9):1881-94. PubmedPMID: 18718396

[13]. Dionne RA, Gordon SM, Rowan J, Kent A, Brahim JS. Dexamethasone suppresses peripheral prostanoid levels without analgesia in a clinical model of acute inflammation. J Oral Maxillofac Surg. 2003 Sep;61(9):997-1003. PubmedPMID: 12966473.

[14]. Sisk AL, Bonnington GJ. Evaluation of methylprednisolone and flurbiprofen for inhibition of the postoperative inflammatory response. Oral Surg Oral Med Oral Pathol. 1985 Aug;60(2):137-45. Pubmed PMID: 3862020.

[15]. Graziani F, D'Aiuto F, Arduino PG, Tonelli M, Gabriele M. Perioperative dexamethasone reduces post-surgical sequelae of wisdom tooth removal. A split-mouth randomized double-masked clinical trial. Int J Oral Maxillofac Surg. 2006 Mar;35(3):241-6. PubmedPMID: 16188428.
[16]. Kumar S, Sneha S. KNOWLEDGE AND AWARENESS REGARDING ANTIBIOTIC PROPHYLAXIS FOR INFECTIVE ENDOCARDITIS AMONG UNDERGRADUATE DENTAL STUDENTS [Internet]. Asian Journal of Pharmaceutical and Clinical Research. 2016. p. 154.

[17]. Jesudasan JS, Wahab PU, Sekhar MR. Effectiveness of $0.2 \%$ chlorhexidine gel and a eugenol-based paste on postoperative alveolar osteitis in patients having third molars extracted: a randomised controlled clinical trial. Br J Oral Maxillofac Surg. 2015 Nov;53(9):826-30. PubmedPMID: 26188932.

[18]. Kumar S, Rahman R. KNOWLEDGE, AWARENESS, AND PRACTICES REGARDING BIOMEDICAL WASTE MANAGEMENT AMONG UNDERGRADUATE DENTAL STUDENTS [Internet]. Vol. 10, Asian Journal of Pharmaceutical and Clinical Research. 2017. p. 341.

[19]. Christabel A, Anantanarayanan P, Subash P, Soh CL, Ramanathan M, Muthusekhar MR, Narayanan V. Comparison of pterygomaxillarydysjunction with tuberosity separation in isolated Le Fort I osteotomies: a prospective, multi-centre, triple-blind, randomized controlled trial. Int J Oral Maxillofac Surg. 2016 Feb;45(2):180-5. Pubmed PMID: 26338075.

[20]. Marimuthu M, Andiappan M, Wahab A, Muthusekhar MR, Balakrishnan A, Shanmugam S. Canonical Wnt pathway gene expression and their clinical correlation in oral squamous cell carcinoma. Indian J Dent Res. 2018 MayJun;29(3):291-297. PubmedPMID: 29900911.

[21]. Packiri S, Gurunathan D, Selvarasu K. Management of Paediatric Oral Ranula: A Systematic Review. J ClinDiagn Res. 2017 Sep;11(9):ZE06-ZE09. PubmedPMID: 29207849.

[22]. Kumar S. Relationship between dental anxiety and pain experience during dental extractions. Asian J Pharm Clin Res. 2017;10(3):458-61.

[23]. Patil SB, Durairaj D, Suresh Kumar G, Karthikeyan D, Pradeep D. Comparison of Extended Nasolabial Flap VersusBuccal Fat Pad Graft in the Surgical Management of Oral Submucous Fibrosis: A Prospective Pilot Study. J Maxillofac Oral Surg. 2017 Sep;16(3):312-321. PubmedPMID: 28717289.

[24]. Rao TD, Santhosh Kumar MP. Analgesic Efficacy of Paracetamol Vs Ketorolac after Dental Extractions [Internet]. Research Journal of Pharmacy and Technology. 2018; 11:3375.

[25]. Abhinav RP, Selvarasu K, Maheswari GU, Taltia AA. The Patterns and Etiology of Maxillofacial Trauma in South India. Ann Maxillofac Surg. 2019 Jan-Jun;9(1):114-117. PubmedPMID: 31293938.

[26]. Kumar S. THE EMERGING ROLE OF BOTULINUM TOXIN IN THE TREATMENT OF OROFACIAL DISORDERS: LITERATURE UPDATE [Internet]. Asian Journal of Pharmaceutical and Clinical Research. 2017;10:21.

[27]. Kumar S. KNOWLEDGE, ATTITUDE AND AWARENESS OF DENTAL UNDERGRADUATE STUDENTS REGARDING HIV/AIDS PATIENTS [Internet]. Asian Journal of Pharmaceutical and Clinical Research. 2017;10:175.

[28]. Sweta VR, Abhinav RP, Ramesh A. Role of Virtual Reality in Pain Perception of Patients Following the Administration of Local Anesthesia. Ann Maxillofac Surg. 2019 Jan-Jun;9(1):110-113. Pubmed PMID: 31293937.

[29]. Patturaja K, Pradeep D. Awareness of Basic Dental Procedure among General Population. Research Journal of Pharmacy and Technology. 2016;9(9):134951.

[30]. Jain SV, Muthusekhar MR, Baig MF, Senthilnathan P, Loganathan S, Wahab $\mathrm{PA}$, et al. Evaluation of three-dimensional changes in pharyngeal airway following isolated lefort one osteotomy for the correction of vertical maxillary excess: a prospective study. Journal of maxillofacial and oral surgery. 2019 Mar 8;18(1):139-46 